\title{
Telluria mixta (Pseudomonas mixta Bowman, Sly, and Hayward 1988) gen. nov., comb. nov., and Telluria chitinolytica sp. nov., Soil-Dwelling Organisms Which Actively Degrade Polysaccharides $\dagger$
}

\author{
J. P. BOWMAN,$^{1} \ddagger$ L. I. SLY,${ }^{1 *}$ A. C. HAYWARD,${ }^{1}$ Y. SPIEGEL, ${ }^{2}$ AND E. STACKEBRANDT ${ }^{1}$ \\ Centre for Bacterial Diversity and Identification, Department of Microbiology, The University of \\ Queensland, Brisbane, Queensland 4072, Australia, ${ }^{1}$ and Department of Nematology, \\ Agricultural Research Organization, Bet Dagan, Israel ${ }^{2}$
}

\begin{abstract}
Pseudomonas mixta (type strain, ACM 1762 [=ATCC 49108], an actively dextranolytic species that possesses both lateral and polar flagella, was compared with the strictly aerobic, rod-shaped, chitinolytic bacterium "Pseudomonas chitinolytica" ACM 3522" (= CNCM I-804) (T = type strain), which has a similar flagellation pattern, by performing phenotypic characterization and DNA-DNA hybridization studies and by analyzing DNA base compositions and 16S rRNA sequences. Our results indicated that " $P$. chitinolytica" ACM 3522 was phenotypically and genotypically distinct from $P$. mixta and other phenotypically analogous Pseudomonas spp., Xanthomonas maltophilia, and other aerobic chitin degraders. The 16S rRNA sequences of strains ACM $1762^{\mathrm{T}}$ and $\mathrm{ACM} 3522^{\mathrm{T}}$ were found to be very similar $(97 \%)$ to each other and indicated that these organisms are proteobacteria that belong to the $\beta$ subclass. The strains were deeply branched in the $\beta$ subclass and were distinct from other pseudomonads, including Pseudomonas cepacia, and from Comamonas testosteroni. On the basis of phenotypic, genotypic, and phylogenetic evidence, it is proposed that $P$. mixta and "P. chitinolytica" ACM $3522^{T}$ represent two distinct species in a new genus called Telluria. Thus, the genus Telluria gen. nov. contains Telluria mixta comb. nov. and Telluria chitinolytica sp. nov., which are strictly aerobic, rod-shaped, soil-dwelling bacteria that are active polysaccharide degraders.
\end{abstract}

The interest in using bacteria as a means of combating postharvest deterioration of sugar cane in Queensland, Australia, during the 1970 s resulted in studies focused on an actively dextranolytic pseudomonad, strain ACM 733 (= UQM 733 = ATCC 49107), which was isolated from a sugar cane rhizosphere (16). The dextranases and other carbohydrate-degrading enzymes produced by this organism have been studied extensively $(4,5,16)$. A partial phenotypic characterization of strain ACM 733 was subsequently performed (1), and the results suggested that this bacterium is a novel organism. A more extensive phenotypic analysis and DNA-DNA hybridization studies placed strain ACM 733 and other phenotypically similar soil isolates in the species Pseudomonas mixta (2). This species was phenotypically similar to members of Pseudomonas rRNA homology group II (15).

$P$. mixta strains are strictly aerobic, rod-shaped bacteria that possess both polar and lateral flagella when they are grown on solid agar media and have the ability to degrade several polysaccharides, including dextran, starch, inulin, pectate, and xylan. A few strains also attack alginate and xanthan gum, but chitinolytic or cellulolytic activity was not observed (2). Later, a chitinolytic, aerobic, rod-shaped bacterium designated "Pseudomonas chitinolytica" $20 \mathrm{M}^{\mathrm{T}}$ ( $\mathrm{T}=$ type strain) which had bionematicidal potential (18) was isolated from soil in Israel. This strain also was subsequently found to form polar and lateral flagella when it was grown on solid media. In this paper, we provide evidence that strain $20 \mathrm{M}^{\mathrm{T}}$ is closely related to $P$. mixta, and on the basis of

\footnotetext{
* Corresponding author.

$\dagger$ I. Chet and Y. Spiegel dedicate this paper to the memory of the late Eli Cohn, our dear colleague and friend.

¥ Present address: Center for Environmental Biotechnology, The University of Tennessee, Knoxville, TN 37932.
}

phylogenetic data we propose that both species should be assigned to a new genus, the genus Telluria.

\section{MATERIALS AND METHODS}

Strains. The following strains were used in this study: " $P$.

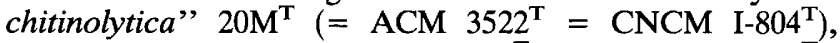
Pseudomonas cepacia ACM 1771 ${ }^{\mathrm{T}}$ (= ATCC 25416 ${ }^{\mathrm{T}}$ ), Pseudomonas gladioli pv. gladioli ACM $1770^{\mathrm{T}}$ (= ATCC $10248^{\mathrm{T}}$ ), $P$. mixta ACM $1762^{\mathrm{T}}$ (= UQM $1762^{\mathrm{T}}=$ ATCC $49108^{\mathrm{T}}$ ), Pseudomonas solanacearum ACM 1648 (biotype III; from A. C. Hayward), and Xanthomonas maltophilia ACM $497^{\mathrm{T}}\left(=\right.$ ATCC $\left.13637^{\mathrm{T}}\right)$.

Isolation. Strain $20 \mathrm{M}^{\mathrm{T}}$ was isolated by using the procedure described below (18). Natural sandy loam soil from Bet Dagan, Israel, containing $14.8 \%$ clay, $38.4 \%$ silt, $37.7 \%$ fine sand, $9.1 \%$ coarse sand, and $0.8 \%$ organic matter $(\mathrm{pH} 7.4)$ was placed into $50-\mathrm{ml}$ pots and mixed with $1 \%$ (wt/wt) natural crustacean shells (previously dried and milled to a powder). The pots were kept moist and maintained in a glasshouse at 27 to $29^{\circ} \mathrm{C}$ for up to 45 days. Portions $(10 \mathrm{~g})$ of soil were suspended in 90 -ml volumes of sterile water in $250-\mathrm{ml}$ flasks, which were shaken vigorously for $30 \mathrm{~min}$ on a rotary shaker. The resulting suspensions $(0.1-\mathrm{ml}$ portions) were appropriately diluted and spread onto agar plates containing $0.2 \%$ (wt/vol) colloidal chitin as the sole carbon source and mineral salts. Colonies producing a halo of chitin degradation were isolated. Strain $20 \mathrm{M}^{\mathrm{T}}$ has been deposited in the Australian Collection of Microorganisms (Department of Microbiology, The University of Queensland) as strain ACM $3522^{\mathrm{T}}$ and in the Pasteur Institute, Paris, France, as strain CNCM I-804 ${ }^{\mathrm{T}}$.

Media and cultivation conditions. Pseudomonas strains were routinely cultivated on chitin or sucrose-peptone agar (9) at $28^{\circ} \mathrm{C}$. Sucrose-peptone agar was used as the basal 
medium for tests that did not require a defined medium and contained (per liter) $20 \mathrm{~g}$ of sucrose, $5 \mathrm{~g}$ of Bacto-Peptone (Difco), $0.25 \mathrm{~g}$ of $\mathrm{MgSO}_{4} \cdot 7 \mathrm{H}_{2} \mathrm{O}, 0.5 \mathrm{~g}$ of $\mathrm{KH}_{2} \mathrm{PO}_{4}$, and, if needed, $15 \mathrm{~g}$ of Bacto-Agar (Difco). The chitin medium used for maintenance of strain ACM $3522^{\mathrm{T}}$ contained (per liter) 15 $\mathrm{g}$ of a chitin suspension (14), $0.5 \mathrm{~g}$ of yeast extract, $1 \mathrm{~g}$ of $\left(\mathrm{NH}_{4}\right)_{2} \mathrm{SO}_{4}, 0.3 \mathrm{~g}$ of $\mathrm{MgSO}_{4} \cdot 7 \mathrm{H}_{2} \mathrm{O}, 1.36 \mathrm{~g}$ of $\mathrm{KH}_{2} \mathrm{PO}_{4}$, and $15 \mathrm{~g}$ of Bacto-Agar.

Phenotypic and genotypic characterization. The procedures used for phenotypic analysis have been described previously (2). DNA was extracted from cells as described previously (17). The DNA base composition was determined by thermal denaturation, using a Gilford model 2600 spectrophotometer equipped with a thermoprogrammer. The $\mathrm{G}+\mathrm{C}$ content was calculated by the point of inflection temperature $\left(T_{i}\right)$ procedure (17). For DNA-DNA studies, DNA held in a ice bath was sheared by using a model 250 Sonifier (Branson, Danbury, Conn.) for $15 \mathrm{~s}$ at maximum power and was dialyzed overnight at $4^{\circ} \mathrm{C}$ in $2 \times \mathrm{SSC}(1 \times \mathrm{SSC}$ is $0.15 \mathrm{M} \mathrm{NaCl}$ plus $0.015 \mathrm{M}$ trisodium citrate, $\mathrm{pH} 7.0$ ). The optical renaturation rate procedure of Huss et al. (10) was used to determine DNA homology values.

Quinone analysis. Quinones were extracted and analyzed by reverse thin-layer chromatography (12). Authentic standards (ubiquinones 6, 7, 9, and 10) were obtained from Sigma Chemical Co., St. Louis, Mo. Quinone extracted from $P$. cepacia $\mathrm{ACM} 1771^{\mathrm{T}}$ was used as the ubiquinone 8 standard (3).

16S rRNA analysis. Bulk RNAs were extracted from strains ACM $3522^{\mathrm{T}}$ and ACM $1762^{\mathrm{T}}$ and were analyzed by using a modification (19) of the reverse transcriptase (13) and terminal transferase (6) procedures. Sequences were aligned with the sequences of various reference proteobacteria (8) (C. R. Woese, Illinois Ribosome Data Project, Department of Microbiology, University of Illinois, Urbana). Pairwise evolutionary distances (expressed as the estimated number of changes per 100 nucleotides) were computed from percentages of similarity by using the correction of Jukes and Cantor (11). Phylogenetic trees were constructed from the distance matrices by the algorithm of De Soete (7).

Nucleotide sequence accession numbers. The sequences of strains ACM $1762^{\mathrm{T}}$ and ACM $3522^{\mathrm{T}}$ have been deposited in the EMBL Data Library, Heidelberg, Germany, under accession numbers X65589 and X65590, respectively.

\section{RESULTS}

Phenotypic characterization. " $P$. chitinolytica" ACM $3522^{\mathrm{T}}$ was found to be a polarly flagellated, gram-negative, rod-shaped organism (Fig. 1) that has several of the salient traits of $P$. mixta, including the development of mixed flagellation when the organism is grown on solid agar media; prominent accumulation of poly- $\beta$-hydroxybutyrate; a highly cartilaginous or elastic colony consistency; sensitivity to $\mathrm{NaCl}$ (no growth at $\mathrm{NaCl}$ concentrations higher than $1.5 \%$ ); a lack of growth on media containing high levels of nitrogenous carbon (e.g., nutrient agar); an ability to grow well at $42^{\circ} \mathrm{C}$; and a predilection for carbohydrates and tricarboxylic cycle intermediates as sources of carbon and energy. " $P$. chitinolytica"' ACM $3522^{\mathrm{T}}$ could be differentiated from $P$. mixta in several ways (Table 1 ); strain ACM $3522^{\mathrm{T}}$ was slightly less biochemically versatile than $P$. mixta. The spectrum of polysaccharide degradation by strain $\mathrm{ACM}$ $3522^{\mathrm{T}}$ was markedly different from the spectrum of polysaccharide degradation by $P$. mixta; the former was not able to hydrolyze dextran or pectate, although it hydrolyzed chitin.

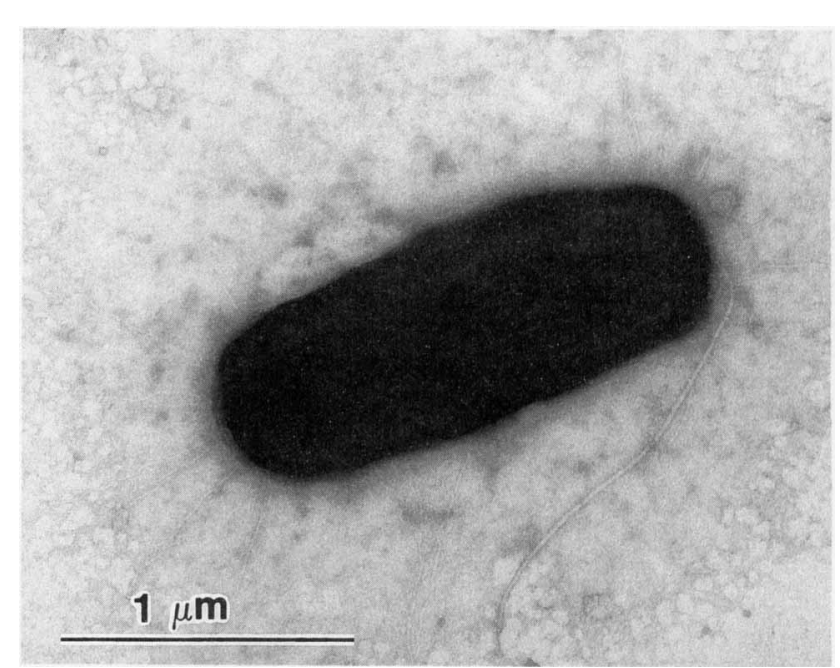

FIG. 1. Electron micrograph of T. chitinolytica ACM $3522^{\mathrm{T}}$, showing the polar flagellum.

Other biochemical differences included a lack of urease and $\beta$-galactosidase activities in ACM $3522^{\mathrm{T}}$, while the lipolytic activity (lecithinase and lipase activities) of strain ACM $3522^{\mathrm{T}}$ was more extensive than that of $P$. mixta strains. The carbon source utilization spectrum of strain ACM $3522^{\mathrm{T}}(36$ of 118 compounds were utilized) was less extensive than that of $P$. mixta (57 of 118 compounds were utilized). Aromatic compounds were not utilized by strain ACM $3522^{\mathrm{T}}$.

Genotypic characterization and quinone content. The DNA of " $P$. chitinolytica" ACM $3522^{\mathrm{T}}$ had a G+C content of 72 mol\%. This value was slightly higher than the values obtained for 23 strains of $P$. mixta (range, 67 to $70 \mathrm{~mol} \%$; average, $69 \mathrm{~mol} \%$ ) (2). DNA-DNA hybridization studies showed that strain ACM $3522^{\mathrm{T}}$ was genetically distinct from $P$. mixta ACM $1762^{\mathrm{T}}$ (14\% DNA homology), $P$. gladioli $\mathrm{pv}$. gladioli ACM $1770^{\mathrm{T}}(13 \%), P$. cepacia ACM $1771^{\mathrm{T}}(13 \%)$, and $X$. maltophilia ACM $497^{\mathrm{T}}(22 \%)$. The quinone contents of strain ACM $3522^{\mathrm{T}}$ and $P$. mixta ACM $1762^{\mathrm{T}}$ appeared to be identical and were similar to those of $P$. cepacia; ubiquinone 8 predominated, and a barely detectable amount of ubiquinone 9 was also present.

Phylogenetic analysis. The unambiguously alignable regions between nucleotide positions 2 and 1476 (Escherichia coli equivalents) of the 16S rRNAs (13) of strains ACM $3522^{\mathrm{T}}$ and ACM $1762^{\mathrm{T}}$ were compared with the same region of various representatives of the $\beta$ subclass of the Proteobacteria. It was found that strains ACM $3522^{\mathrm{T}}$ and ACM $1762^{\mathrm{T}}$ were closely related and exhibited $3.6 \%$ divergence in their sequences. The sequences were relatively distinct from those of other members of the $\beta$ subclass, including $P$. cepacia and Comamonas testosteroni ( $>11 \%$ sequence divergence). The closest relatives detected were members of the genera Nitrosomonas and Nitrosolobus (Table 2 and Fig. 2).

\section{DISCUSSION}

It was originally suspected that $P$. mixta and " $P$. chitinolytica" might be related to members of Pseudomonas rRNA homology group II $(2,15)$, especially $P$. cepacia and $P$. gladioli. This conclusion was based on the limited number of phenotypic criteria which help distinguish the various Pseudomonas rRNA homology groups from each other and from other phenotypically related bacteria. In the case of 
TABLE 1. Phenotypic characteristics that distinguish the species of Telluria gen. nov.

\begin{tabular}{|c|c|c|}
\hline Characteristic $^{a}$ & $\begin{array}{l}\text { T. mixta } \\
\text { (23 strains) }^{b}\end{array}$ & $\begin{array}{l}\text { T. chitinolytica } \\
\text { ACM } 3522^{\mathrm{T}}\end{array}$ \\
\hline Yellow pigmentation & $-^{c}$ & + \\
\hline Nitrate reduced to nitrite & d & - \\
\hline Urease and $\beta$-galactosidase activities & + & - \\
\hline Lecithinase activity (egg yolk) & - & + \\
\hline \multicolumn{3}{|l|}{ Hydrolysis of: } \\
\hline Chitin and tibutyrin & - & + \\
\hline $\begin{array}{l}\text { Dextran, pectate (pH } 5 \text { to } 8.3 \text { ), and } \\
\text { Tween } 20\end{array}$ & + & - \\
\hline Growth at $45^{\circ} \mathrm{C}$ & - & + \\
\hline \multicolumn{3}{|l|}{ Utilization of: } \\
\hline $\begin{array}{l}\text { DL-Arabinose, lactose, dextran, } \\
\text { butyrate, DL-glycerate, glycolate, } \\
\text { benzoate, } p \text {-hydroxybenzoate, } \\
\text { DL-serine, DL-threonine, L-argi- } \\
\text { nine, L-citrulline, L-ornithine, and } \\
\text { L-phenylalanine }\end{array}$ & + & - \\
\hline Glycerol and acetamide & - & + \\
\hline $\begin{array}{l}\text { L-Tyrosine, poly- } \beta \text {-hydroxybutyrate, } \\
\text { heptanoate, caprylate, mannitol, } \\
\text { phenol, } m \text {-hydroxybenzoate, } \\
\text { benzoyl-formate, DL-mandelate, } \\
\text { and quinate }\end{array}$ & d & - \\
\hline L-Histidine & d & + \\
\hline $\mathrm{G}+\mathrm{C}$ content $(\mathrm{mol} \%)^{d}$ & $67-70$ & 72 \\
\hline
\end{tabular}

${ }^{a}$ The following tests were positive for both T. mixta and T. chitinolytica: oxidative reaction in Hayward's oxidation-fermentation test; catalase; oxidase; poly- $\beta$-hydroxybutyrate accumulation; growth at $42^{\circ} \mathrm{C}$; hydrolysis of starch, xylan, gelatin, casein, Tween 40 , Tween 60 , Tween 80 , DNA, and esculin; gluconate oxidation; phosphatase; arylsulfatase; growth on King A and King B media (very poor to poor growth) and glucose-nitrate medium (good growth); tolerance to $0.5 \% \mathrm{NaCl}$ (very poor to poor growth only); and utilization of D-xylose, L-rhamnose, D-fructose, D-galactose, D-glucose, D-mannose, D-melezitose, maltose sucrose, cellobiose, trehalose, inulin, starch, xylan, gluconate, 2-ketogluconate, glucoronate, galacturonate, mucate, saccharate, $\beta$-hydroxybutyrate, malonate, succinate, DL-lactate, fumarate, DL-malate, pyruvate, $\mathrm{L}-(+)$-tartarate, citrate, $\mathrm{D}$-alanine, $\mathrm{L}$-alanine, $\mathrm{L}$-aspartate, and L-glutamate as sole sources of carbon and energy. The following tests were negative for both $T$. mixta and $T$. chitinolytica: arginine dihydrolase; hydrogen autotrophy; denitrification; growth at $4^{\circ} \mathrm{C}$; hydrolysis of cellulose, xanthan gum, and alginate; hydrogen sulfide production; levan production from sucrose; tolerance to $>1.5 \% \mathrm{NaCl}, 0.03 \%$ cetrimide, and $0.0075 \% \mathrm{KCN}$; growth on MacConkey agar; fluorescent pigment production; hemolysis of sheep blood; and utilization of D-ribose, acetate, propionate, isobutyrate, valerate, isovalerate, caproate, pelargonate, caprate, oxalate, glutarate, adipate, pimelate, suberate, azelate, sebacate, maleate, $\mathrm{D}-(-)$ tartrate, meso-tartrate, citraconate, itaconate, mesaconate, levulinate, ethanol, propanol, butanol, 1,2-ethanediol, 1,3-propanediol, 2,3-butanediol, adonitol, meso-erythritol, meso-inositol, sorbitol, anthranilate, $p$-aminobenzoate, benyzlamine, sarcosine, betaine, $\beta$-alanine, DL-2-aminobutyrate, DL-4-aminobutyrate, DL-2-aminovalerate, DL-5-aminovalerate, L-valine, L-proline, L-hydroxyproline, L-glutamine, L-lysine, L-tryptophan, L-methionine, L-cystein, putrescine, spermine, ethanolamine, histamine, $\alpha$-amylamine, tryptamine, and pantothenate as sole sources of carbon and energy.

${ }^{b}$ Data from reference 2 .

$c+$, present in 90 to $100 \%$ of the strains; $d$, present in 11 to $89 \%$ of the strains; -, present in 0 to $10 \%$ of the strains.

${ }^{d}$ Determined by the $T_{i}$ method.

rRNA homology group II species such as $P$. cepacia, these phenotypic characteristics include ortho cleavage of protocatechuate; growth at $42^{\circ} \mathrm{C}$; lack of arginine dihydrolase and denitrification activity; strong poly- $\beta$-hydroxybutyrate accumulation; and a $\mathrm{G}+\mathrm{C}$ content greater than $65 \mathrm{~mol} \%(15)$. The results of a phylogenetic analysis (in which 16S rRNA sequences were used) showed that $P$. mixta and " $P$. chitinolytica" ACM $3522^{\mathrm{T}}$ were members of the $\beta$ subclass, but despite their superficial phenotypic resemblance to $P$. cepacia and to $C$. testosteroni, they were phylogenetically dis-

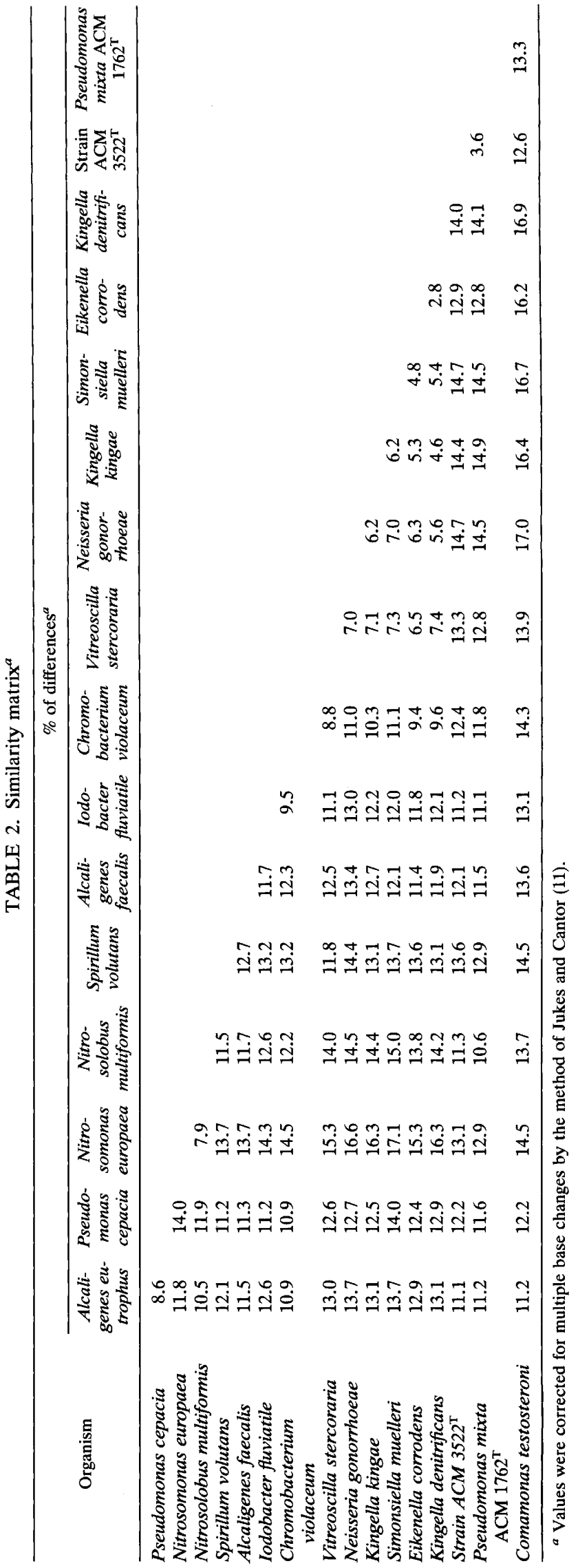




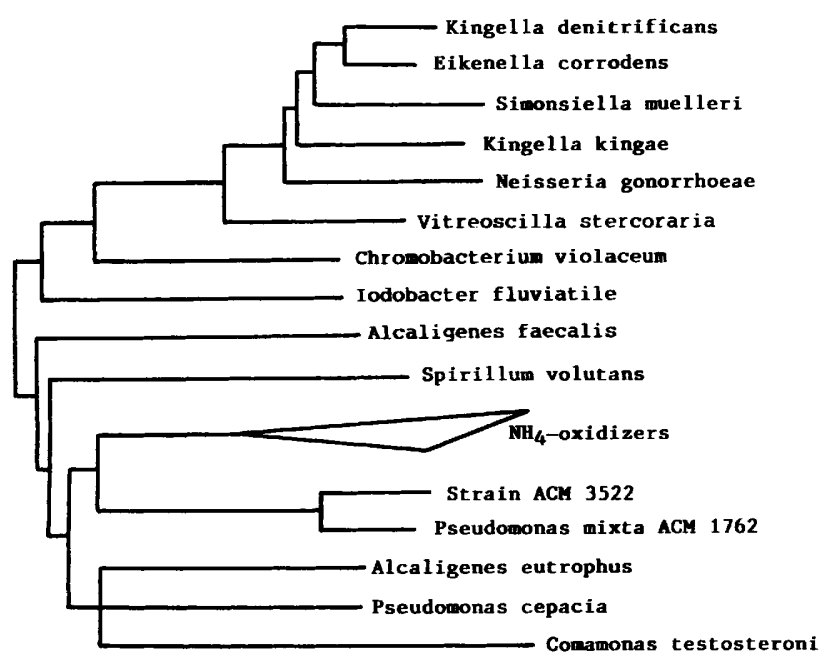

FIG. 2. Phylogenetic tree of the $\beta$ subclass of the Proteobacteria. The scale bar represents a $2 \%$ difference in nucleotide sequences, as determined by measuring the lengths of the horizontal lines connecting two species.

tinct. A common feature of all of these organisms is the predominance of ubiquinone 8 (3), which supports the hypothesis that they are related at a higher taxonomic level.

Phenotypically, $P$. mixta and " $P$. chitinolytica" ACM $3522^{\mathrm{T}}$ could be differentiated from the species belonging to
Pseudomonas rRNA homology group II (also referred to as the $P$. solanacearum branch [21]) and other strictly aerobic, high-G+C-content, rod-shaped genera belonging to rRNA superfamily III (effectively the $\beta$ subclass) in a number of ways, including formation of highly elastic or cartilaginous colonies upon isolation; very poor or no growth on media (such as nutrient agar) which contain a high level of nitrogenous carbon; formation of lateral flagella and a single polar flagellum when cultures are grown on solid media; and a propensity for the utilization of complex and simple carbohydrates (Table 3). Phylogenetic data provided good evidence that $P$. mixta and " $P$. chitinolytica" ACM $3522^{\mathrm{T}}$ represent distinct species in a new genus. Thus, it is proposed that $P$. mixta and " $P$. chitinolytica" should be assigned to the genus Telluria as Telluria mixta gen. nov., comb. nov. and Telluria chitinolytica sp. nov., respectively.

Description of Telluria gen. nov. Telluria (Tel.lu'.ri.a. L. fem. n. Tellus, a Roman goddess of the earth, also the ground or earth; M. L. fem. n. Telluria, from the earth). Gram negative. Cells are straight rods that are 0.5 to $1.0 \mu \mathrm{m}$ wide and 2.0 to $3.0 \mu \mathrm{m}$ long. Occasionally filamentous cells up to $30 \mu \mathrm{m}$ long are formed, a tendency which increases in older cultures. The cells occur singly, in pairs, or in short chains. When cultures are grown in liquid media, a single polar flagellum is formed on each cell, while on solid media additional lateral flagella occur. Strongly accumulates poly$\beta$-hydroxybutyrate. Strictly aerobic, growing only as a surface pellicle in static liquid cultures. Chemoheterotrophic. Incapable of gaining energy chemolithotrophically from hydrogen. Denitrification does not occur. Arginine dihydrolase is absent. Good growth occurs on media containing carbohy-

TABLE 3. Phenotypic characteristics that differentiate $T$. mixta and $T$. chitinolytica from other high-G+C-content, strictly oxidative aerobes belonging to the $\beta$ subclass of the Proteobacteria (rRNA superfamily III)

\begin{tabular}{|c|c|c|c|c|c|c|c|}
\hline Characteristic $^{a}$ & $\begin{array}{l}\text { Telluria gen. } \\
\text { nov. }\end{array}$ & $\begin{array}{l}\text { Pseudomonas so- } \\
\text { lanacearum } \\
\text { branch }\end{array}$ & Comamonas & Acidovorax & Hydrogenophaga & $\begin{array}{l}\text { Variovorax } \\
\text { paradoxus }\end{array}$ & Xylophilus \\
\hline \multicolumn{8}{|l|}{ Flagellation } \\
\hline Mixed ( 1 polar and $>1$ lateral) & $t^{b}$ & - & - & - & - & - & - \\
\hline Polar $(\geq 1)$ & + & + & - & + & + & - & + \\
\hline Peritrichous & - & - & - & - & - & + & - \\
\hline Bipolar tufts & - & - & + & - & - & - & - \\
\hline Hydrogen autotrophy & - & - & - & d & + & d & - \\
\hline Hydrolysis of starch & + & $\mathrm{D}$ & - & - & - & - & d \\
\hline Growth on nutrient agar & - & + & + & + & + & + & - \\
\hline Tolerance to $1.5 \% \mathrm{NaCl}$ & - & + & + & + & + & + & - \\
\hline \multicolumn{8}{|l|}{ Utilization of: } \\
\hline Lactose & $\mathrm{D}$ & - & - & - & - & - & - \\
\hline Maltose & + & $--^{c}$ & - & - & - & - & - \\
\hline Inulin & + & - & - & - & - & - & - \\
\hline Acetate & - & + & + & + & + & + & - \\
\hline Propionate & - & + & + & d & $\mathrm{d}$ & d & - \\
\hline Isobutyrate & - & $t^{d}$ & + & d & - & d & ND \\
\hline Valerate & - & $t^{d}$ & + & + & - & d & - \\
\hline meso-Inositol & - & $t^{e}$ & d & - & + & $\mathrm{d}$ & ND \\
\hline B-Alanine & - & + & d & d & - & d & ND \\
\hline DL-4-Aminobutyrate & - & + & d & + & - & + & - \\
\hline L-Proline & - & + & + & + & + & + & ND \\
\hline Occurrence ${ }^{f}$ & $\mathbf{S}$ & S, FW, CS, IP & S, FW, CS & $\mathrm{S}, \mathrm{FW}, \mathrm{CS}$ & S, FW & S, FW & IP \\
\hline $\mathrm{G}+\mathrm{C}$ content $(\mathrm{mol} \%)$ & $67-72$ & $64-69$ & $60-69$ & $62-66$ & $65-69$ & $67-69$ & $68-69$ \\
\hline
\end{tabular}

${ }^{a}$ Data from references 15 and 20 through 24.

$b+$, present in 90 to $100 \%$ of the strains; d, present in 11 to $89 \%$ of the strains; -, present in 0 to $10 \%$ of the strains; D, varies among species; ND, no data.

c Positive in Pseudomonas mallei and Pseudomonas pseudomallei.

${ }^{d}$ Negative in Pseudomonas mallei.

e Negative in Pseudomonas pickettii.

${ }^{f}$ S, soil; FW, fresh water; CS, clinical samples; IP, infected plants (phytopathogenic). 
drates and an inorganic or organic combined nitrogen source. Much poorer growth occurs on media lacking carbohydrates. $\mathrm{NaCl}$ sensitive; completely inhibited by $\mathrm{NaCl}$ concentrations greater than $1.5 \%$, and only poor growth occurs at an $\mathrm{NaCl}$ concentration of $0.5 \%$. Actively utilizes complex polysaccharides, including starch and xylan, as well as other polysaccharides which vary among the species. Cellulose is not hydrolyzed. Hydrolyzes gelatin, casein, DNA, esculin, and Tween 40, Tween 60 , and Tween 80 . Produces phosphatase and arylsulfatase. Grows well at temperatures between 20 and $45^{\circ} \mathrm{C}$ and optimally at 30 to $35^{\circ} \mathrm{C}$; optimal growth occurs at $\mathrm{pH}$ 7.0. The major quinone is ubiquinone 8 . The DNA base composition varies between 67 and $72 \mathrm{~mol} \% \mathrm{G}+\mathrm{C}$ (as determined by the $T_{i}$ method). The only known habitat is soil, particularly the rhizosphere. The type species is Telluria mixta (formerly Pseudomonas mixta). The genus Telluria is a member of the $\beta$ subclass of the Proteobacteria and is not closely related phylogenetically to other taxa.

Description of Telluria mixta (Bowman, Sly, and Hayward 1988) comb. nov. The description of Telluria mixta (mix'ta. L. adj. mixtus, mixed; M. L. fem. adj. mixta, mixed, referring to mixed flagellation) is the same as that given above for the genus; additional biochemical and nutritional characteristics are shown in Table 1. T. mixta strains have been isolated from various soils in Queensland, Australia (2). The average $\mathrm{G}+\mathrm{C}$ content of the DNA of the species is 69 mol\% (as determined by the $T_{i}$ method). The type strain is strain ACM 1762 (= UQM $1762=$ ATCC 49108).

Description of Telluria chitinolytica sp. nov. The description of Telluria chitinolytica (chi.tin.o.lyt'i.ca. chem. term chitin, chitin, a polysaccharide; Gr. adj. lytos, soluble; M. L. fem. adj. chitinolytica, dissolving chitin) is the same as that given above for the genus; additional biochemical and nutritional characteristics are shown in Table $1 . T$. chitinolytica is monotypic, and type strain ACM 3522 (= CNCM I-804) was isolated from a loamy soil from Bet Dagan, Israel (18). The $\mathrm{G}+\mathrm{C}$ content of the DNA of strain ACM $3522^{\mathrm{T}}$ is $72 \mathrm{~mol} \%$ (as determined by the $T_{i}$ method).

\section{ACKNOWLEDGMENTS}

We thank E. Cohn (Agricultural Research Organisation, Bet Dagan, Israel) and I. Chet (Department of Plant Pathology and Microbiology, The Hebrew University of Jerusalem, Rehovot, Israel) for assistance with the isolation of strain $20 \mathrm{M}^{\mathrm{T}}$, Rick Webb and Helen Hosmer for the electron microscopy, and I. C. MacRae for use of a gas chromatograph for the acetylene reduction assay.

\section{REFERENCES}

1. Blackall, L. L., A. C. Hayward, and L. I. Sly. 1985. Cellulolytic and dextranolytic gram-negative bacteria: revival of the genus Cellvibrio. J. Appl. Bacteriol. 59:81-97.

2. Bowman, J. P., A. C. Hayward, and L. I. Sly. 1988. Pseudomonas mixta sp. nov., a bacterium from soil with degradative activity on a variety of complex polysaccharides. Syst. Appl. Microbiol. 11:53-59.

3. Collins, M. D., and D. Jones. 1981. Distribution of isoprenoid structural types in bacteria and their taxonomic implications. Microbiol. Rev. 45:316-354.

4. Covacevich, M. T., and G. N. Richards. 1978. Purification of intracellular dextranases and $\beta$-glucosidases from Pseudomonas UQM 733. Carbohydr. Res. 64:169-180.

5. Covacevich, M. T., and G. N. Richards. 1979. Modes of action of intracellular dextranase and three oligoglucanases from Pseudomonas UQM 733. Carbohydr. Res. 70:283-293.

6. De Borde, C. C., W. N. Clayton, M. L. Herlocher, and H. F. Maassab. 1986. Resolution of a common RNA sequencing ambiguity by terminal deoxynucleotidyl transferase. Anal. Bio- chem. 157:275-282.

7. De Soete, G. 1983. A least square algorithm for fitting additive trees to proximity data. Psychometrika 48:621-626.

8. Dewhirst, F. E., B. J. Paster, and P. L. Bright. 1989. Chromobacterium, Eikenella, Kingella, Neisseria, Simonsiella, and Vitreoscilla species comprise a major branch of the beta group Proteobacteria by $16 \mathrm{~S}$ ribosomal ribonucleic acid sequence comparison: transfer of Eikenella and Simonsiella to the family Neisseriaceae (emend.). Int. J. Syst. Bacteriol. 39:258-266.

9. Hayward, A. C. 1964. Characteristics of Pseudomonas solanacearum. J. Appl. Bacteriol. 27:265-277.

10. Huss, V. A. R., H. Festl, and K. H. Schleifer. 1983. Studies on the spectrophotometric determination of DNA hybridization from renaturation rates. Syst. Appl. Microbiol. 4:184-192.

11. Jukes, T. H., and C. R. Cantor. 1969. Evolution of protein molecules, p. 21-132. In H. N. Munro (ed.), Mammalian protein metabolism. Academic Press, New York.

12. Karr, D. E., W. F. Bibb, and C. W. Moss. 1981. Isoprenoid quinones of the genus Legionella. J. Clin. Microbiol. 15:1044-1048.

13. Lane, D. J. 1991. 16S/23S rRNA sequencing, p. 115-176. In E. Stakebrandt and M. Goodfellow (ed.), Nucleic acid techniques in bacterial systematics. John Wiley \& Sons, New York.

14. Monreal, J., and E. T. Reese. 1969. The chitinase of Serratia marcescens. Can. J. Microbiol. 15:689-696.

15. Palleroni, N. J. 1984. Genus I. Pseudomonas Migula 1894, p. 141219. In N. R. Krieg and J. G. Holt (ed.), Bergey's manual of systematic bacteriology, vol. 1. The Williams \& Wilkins Co., Baltimore.

16. Richards, G. N., and M. Streamer. 1972. Studies on dextranase. I. Isolation of extracellular bacterial dextranases. Carbohydr. Res. 62:191-196.

17. Sly, L. I., L. L. Blackall, P. C. Kraat, T. Tian-Shen, and V. Sangkhobol. 1986. The use of second derivative plots for the determination of mol\% guanine plus cytosine of DNA by the thermal denaturation method. J. Microbiol. Methods 5:139-156.

18. Spiegel, Y., E. Cohn, S. Galper, E. Sharon, and I. Chet. 1991. Evaluation of a newly isolated bacterium, Pseudomonas chitinolytica sp. nov., for controlling the root-knot nematode Meloidogyne javanica. Biocontrol Sci. Technol. 1:115-125.

19. Stackebrandt, E., and O. Charfreitag. 1990. Partial 16S rRNA primary structure of five Actinomyces species: phylogenetic implications and development of an Actinomyces israeliispecific oligonucleotide probe. J. Gen. Microbiol. 136:37-43.

20. Willems, A., J. Busse, M. Goor, B. Pot, E. Falsen, E. Jantzen, B. Hoste, M. Gillis, K. Kersters, G. Auling, and J. De Ley. 1989. Hydrogenophaga, a new genus of hydrogen-oxidizing bacteria that includes Hydrogenophaga flava comb. nov. (formerly Pseudomonas flava), Hydrogenophaga palleronii (formerly Pseudomonas palleronii), Hydrogenophaga pseudoflava (formerly Pseudomonas pseudoflava and "Pseudomonas carboxydoflava"), and Hydrogenophaga taeniospiralis (formerly Pseudomonas taeniospiralis). Int. J. Syst. Bacteriol. 39:319-333.

21. Willems, A., J. De Ley, M. Gillis, and K. Kersters. 1991. Comamonadaceae, a new family encompassing the acidovorans rRNA complex, including Variovorax paradoxus gen. nov., comb. nov., for Alcaligenes paradoxus (Davis 1969). Int. J. Syst. Bacteriol. 41:445-450.

22. Willems, A., E. Falsen, B. Pot, E. Jantzen, B.Hoste, P. Vandamme, M. Gillis, K. Kersters, and J. De Ley. 1990. Acidovorax, a new genus for Pseudomonas facilis, Pseudomonas delafieldii, EF group 13, EF group 16, and several clinical isolates, with the species Acidovorax facilis comb. nov., Acidovorax delafieldii comb. nov., and Acidovorax temperans sp. nov. Int. J. Syst. Bacteriol. 40:384-398.

23. Willems, A., M. Gillis, K. Kersters, L. Van den Broecke, and J. De Ley. 1987. Transfer of Xanthomonas ampelina Panagopoulos 1969 to a new genus, Xylophilus gen. nov., as Xylophilus ampelinus (Panagopoulos 1969) comb. nov. Int. J. Syst. Bacteriol. 37:422-430.

24. Willems, A., B. Pot, E. Falsen, P. Vandamme, M. Gillis, K. Kersters, and J. De Ley. 1991. Polyphasic taxonomic study of the emended genus Comamonas: relationship to Aquaspirillum aquaticum, E. Falsen group 10, and other clinical isolates. Int. J. Syst. Bacteriol. 41:427-444. 